FedUni ResearchOnline

http://researchonline.federation.edu.au

This is the peer reviewed version of the following article:

Kattel, G., Gell, P., et al. (2015) Tracking a century of change in trophic structure and dynamics in a floodplain wetland: Integrating palaeological and palaeoisotopic evidence. Freshwater Biology, 60(4), 711-723; which has been published in final form at http://doi.org/10.1111/fwb.12521. This article may be used for non-commercial purposes in accordance with Wiley Terms and Conditions for Self-Archiving. 


\section{Tracking a century of change in trophic structure and dynamics in a floodplain wetland: integrating palaeo-ecological, and palaeo-isotopic, evidence}

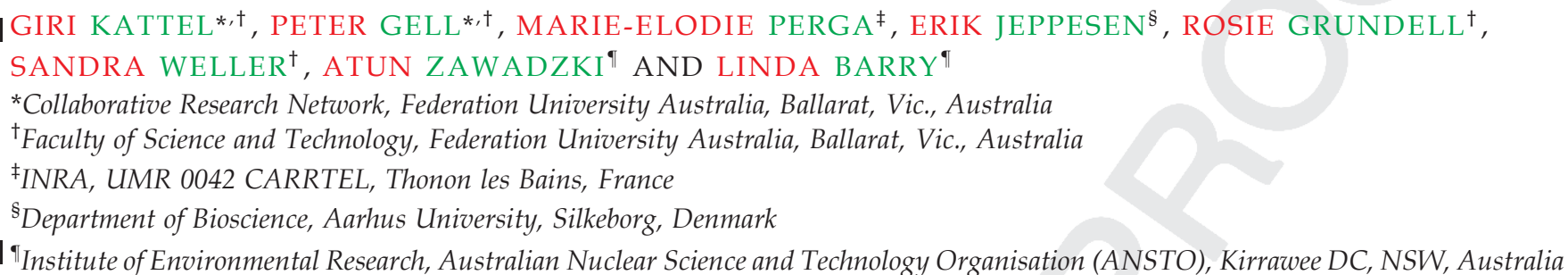

\section{SUMMARY}

1. The palaeoecological assessment, and the use of stable isotopes of carbon in subfossils of herbivores and omnivores, represents a novel approach to understand transitions in past food-web structure and the dynamics of lake ecosystems in response to natural perturbations and human impacts. Combined with records of subfossil assemblages of cladocerans and chironomids, it may be possible to decipher whether changes are attributable to external forces or internally derived system shifts.

2. A sediment record taken from the shallow (2.3 m depth) Kings Billabong in the River Murray floodplain (Australia) was analysed to explore changes in trophic dynamics over the past century. 3. The palaeoecological assessment revealed that littoral assemblages of cladocerans and benthic diatoms were gradually replaced by planktonic (planktonic and facultative planktonic) assemblages after river regulation in the 1920s.

4. The stable isotopic composition of carbon $\left(\mathrm{d}^{13} \mathrm{C}\right)$, derived from chironomid head capsules, was relatively constant down-core, ranging between $-26.1 \&$ and $-24.0 \&$, and coincided largely with the $\mathrm{d}^{13} \mathrm{C}$ of bulk sediment samples (-25.6\& to $-22.0 \&$ ). The $\mathrm{d}^{13} \mathrm{C}$ values of pelagic (Daphnia) and ubiquitous (Bosmina, Alona) cladocerans, however, varied markedly, with that for Daphnia between -29.8\& $(10-20 \mathrm{~cm})$ and $-23.2 \&(60-70 \mathrm{~cm})$, and for ubiquitous cladocerans, between $-29.4 \&(20-30 \mathrm{~cm})$ and $-24.5 \&(80-70 \mathrm{~cm})$.

5. The temporal changes in the $d^{13} \mathrm{C}$ values of cladocerans also suggest a gradual transition from a macrophyte-dominated state to a phytoplankton-dominated state after river regulation and further indicate changes in the horizontal migration behaviour of Daphnia depending on macrophyte abundance and predation risk.

6. Our study demonstrates the potential of reconstructing, more precisely, the trophic dynamics of large river floodplain lakes and their ecological resilience by combining subfossil analyses with stable isotope analyses of selected subfossil groups.

Keywords: Kings Billabong, palaeo-food-web structure, River Murray system Australia, stable carbon isotope, subfossil cladocerans and chironomids

Introduction

In large river floodplains, the patterns of river flow and flood pulses are highly variable, resulting in pronounced variation in exchange rates of nutrients, organic matter $(\mathrm{OM})$ and organisms between the river and its associated wetlands over space and time (Vannote et al., 1980). Locally derived algae can be a significant source of

Correspondence: Giri Kattel, Collaborative Research Network, Federation University Australia, Mt Helen, Ballarat, Vic 3350, Australia,

E-mail: g.kattel@federation.edu.au 


\section{G. Kattel et al.}

carbon at the base of the food web, but the carbon derived from the riparian vegetation can also add to local autochthonous production at degree that depends on the frequency and duration of the flood pulse (Thorp \& Delong, 1994; Wehr \& Descy, 1998). Flooding further brings terrestrial-derived plant and animal biomasses to the total carbon pool of the wetland (Burford et al., 2008). Any natural or anthropogenic alterations in the connectivity between rivers and wetlands are, therefore, expected to influence riverine food webs significantly.

The natural flood pattern of the River Murray in south-east Australia has been disrupted following the arrival of Europeans around 1850. An extensive network of dams, weirs and locks was built on the river, mostly from the 1920s, and its catchment has been transformed for agriculture (Ogden, 2000; Gell et al., 2009). The construction of dams, originally to facilitate navigation but now mostly to provide water for irrigation, has disrupted downstream flow, altering nutrient transport and the exchange of fixed carbon between the river and its wetlands (Gehrke \& Harris, 2000; King, Humphries \& Lake, 2003; Frazier \& Page, 2006). In sites closely to the weir pools, permanent inundation has led to the disappearance of invertebrates and plants adapted to low water, and the loss of floodplain vegetation, such as river red gum (Eucalyptus camaldulensis) and lignum Muehlenbeckia florulenta (Kingsford, 2000), characteristic of early succession after drawdown. In wetlands distant from the channel, prolonged drought has forced herbivores and fish to feed on filamentous algae confined to small waterholes (Bunn, Davis \& Winning, 2003; Burford et al., 2008). Prolonged flooding, on the other hand, has reduced the density of submerged vegetation and led to the establishment of the emergent Cumbungi-Typha spp. vegetation (Nielsen et al., 2000). Evidence for this also comes from palaeoecological investigations in billabongs across the middle reaches of the River Murray (Reid et al., 2002). As a result of the switch in the density of submerged aquatic macrophytes, the sources of carbon to floodplain wetlands of the River Murray are also thought to have been altered internally by river regulation.

In shallow lakes, a transition from a clear-water, macrophyte-rich state to a phytoplankton-dominated, turbid regime is often accompanied by a shift in floral and faunal assemblages and from littoral-benthic to pelagic carbon pathways and energy flow (Vadeboncoeur et al., 2003). In the sediment record of subfossils, this is evident in an increase in the littoral to planktonic (L:P) ratios of consumers, such as cladocerans (Jeppesen et al., 2001). The disruption in wetland connectivity, and the implications for the quantity and quality of external inputs of carbon and nutrients to floodplain wetlands of south-east Australia, has been well investigated (Bunn et al., 2003; Burford et al., 2008). However, how the associated loss of benthic-periphytic submerged floral community has affected the internal dynamics of carbon is not well known. Stable isotope ratios of carbon $\left(d^{13} \mathrm{C}\right)$ in organic matter, and in remains of various organisms, may be useful to study changes in the internal $C$ dynamics (Perga, 2010), as $d^{13} \mathrm{C}$ values are reported to vary among primary producers, but to change little with trophic transfer, thereby allowing the ultimate sources of dietary carbon to be determined (Post, 2002).

The purpose here was to investigate how the trophic dynamics changed in a floodplain wetland in south-east Australia, before and after human disturbance. It is assumed that a clear-water, littoral-benthic-derived food web collapsed following river regulation during the late 1920s and that the base of the food web switched as a result of a shift to a phytoplankton-dominant pelagic regime. We aimed to describe the ecosystem in the past: changes in habitat diversity were documented from diatom and cladoceran subfossil assemblages (Ogden, 2000; Reid et al., 2007), while changes in the carbon source fuelling the riverine food web were investigated from the $\mathrm{d}^{13} \mathrm{C}$ values of sediments and invertebrate subfossils.

Recently, the $\mathrm{d}^{13} \mathrm{C}$ values derived from subfossil chironomid head capsules and cladocerans have been used successfully to map the energy flow and to infer palaeofood-web dynamics in European lakes (Perga, 2010; Frossard et al., 2014). This has been possible due to the isotope ratio mass spectrometry (IRMS) technique enabling measurement of $\mathrm{d}^{13} \mathrm{C}$ values from small samples of the head capsules of subfossil chironomids and of cladocerans (Perga, 2010; Van Hardenbroek et al., 2010).

For this study, $\mathrm{d}^{13} \mathrm{C}$ measurements were performed on subfossil taxa selected based on their abundance, food preferences and the capacity to separate their remains. Bosmina and Alona produce single eggs that can be relatively easily isolated from the sediment. The feeding of Bosmina and small Alona is not well studied, but their ubiquity, in terms of habitat, suggests they are not food specialists (DeMott, 1989). For instance, at the time of food shortage, Bosmina thrives by eating non-photosynthetic organisms, including protozoa and eubacteria (as does Alona) in the near-shore littoral environment, more efficiently than Daphnia (Smiley \& Tessier, 1998). Their stable isotopic composition of carbon was, therefore, considered as representative of that of the source dominating the carbon pool (phytoplankton and/or the 
terrestrial and littoral aquatic primary producers) at the time of sampling. In contrast, Daphnia is a typical pelagic filter-feeder (Lampert, 1989) producing eggs that can be easily distinguished from those of Bosmina/Alona. Their isotope composition has been repeatedly shown to reflect pelagic primary production (Perga \& Gerdeaux, 2006; Francis et al., 2011). Lastly, the ${ }^{13} \mathrm{C}$ of chironomid head capsules was expected to reflect benthic carbon sources. A comparison of the $\mathrm{d}^{13} \mathrm{C}$ values between pelagic Daphnia and ubiquitous (e.g. Bosmina, small Alona) cladocerans and benthic chironomids in the system, over a 100-year timescale, should reveal any changes in the food web before, during and after a transition from a clear-water, littoral-benthic regime (high diversity in $\mathrm{d}^{13} \mathrm{C}$ values among taxa) to a turbid water, phytoplankton-dominated regime (homogeneity of $d^{13} \mathrm{C}$ between taxa).

\section{Methods}

\section{Study site}

Kings Billabong, a shallow (maximum depth c. $2.3 \mathrm{~m}$ ) wetland, is located adjacent to the lower River Murray near the city of Mildura (north-west Victoria) (Kattel, Dong \& Yang, 2014). Historically, Kings Billabong was closely associated with the Nyeri Nyeri aboriginal community. The remarks of William Splatt in 1853, that 'The aboriginal inhabitants of the lower Murray are more numerous and a finer race than any other native tribe I have seen in Australia. The comparatively warm, short winter of this neighbourhood, and the abundance of fish and game, may in part account for this' reveal the value of fish in Kings Billabong to the economy of the aboriginal community (McBride, 1898). A variety of fish species, including the endemic Murray cod (Maccullochella peelii peelii), golden perch (Macquaria ambigua), Australian smelt (Retropinna semoni), fly-specked hardyhead (Craterocephalus stercusmuscarum fulvus), flat-headed gudgeon and bony herring (Nematalosa erebi), as well as introduced species such as mosquito fish (Gambusia holbrooki), has been collected by the Murray Darling Freshwater Research Centre (MDFRC) from Kings Billabong during their routine monitoring programme.

In its natural condition, Kings Billabong was intermittently filled at times of high flows in the Murray River. However, since the intensification of the early European migrant settlement in the Victorian Mallee region from 1891 to 1923 (www.murrayriver.com.au), the landscape across the catchment has changed substantially (MCMA, 2006). The natural flow of the Murray has been signifi- cantly modified by the construction and operation of a series of locks, weirs and upstream storages (Gippel \& Blackham, 2002). These changes have affected the hydrology and, in particular, the variability, duration and frequency of flows in the river (Gippel \& Blackham, 2002). While Kings Billabong was first used as a water storage basin for irrigation in 1896, major river regulation was imposed on the system through the commissioning of a network of impoundments between 1922 and 1937, and these are likely to have modified the connectivity of Kings Billabong to the river (Gippel \& Blackham, 2002). Artificial flooding linked to the nearby weir pool of Lock 9 at Mildura, transformed Kings Billabong to a permanently waterlogged area, leading to the dieback of river red gum forests and the establishment of fringing Cumbungi (Typha sp.) vegetation. The loss of river red gum continued until the 1950s, as their timber was used to fuel steam-operated pumps and paddle boats on the river (Parks Victoria, 2008).

\section{${ }^{210} \mathrm{~Pb}$ dating}

A 94-cm-long, 80-mm-diameter piston sediment core was collected from the deepest point $(c .2 .3 \mathrm{~m})$ of the wetland in September 2011 and used for analyses of subfossil cladocerans, chironomids and diatoms, stable isotopes of carbon and nitrogen, as well as age modelling. The ${ }^{210} \mathrm{~Pb}$ age modelling (Appleby, 2001) was based on CIC (constant initial concentration) and CRS (constant rate of supply) models using a total of 9 subsamples showing ${ }^{210} \mathrm{~Pb}$ activity down to $51 \mathrm{~cm}$. The samples were analysed at the Australian Nuclear Science and Technology Organisation (ANSTO), Lucas Heights following the methods described by Harrison, Heijnis \& Caprarelli (2003).

\section{Subfossil diatom analyses}

High-resolution subsampling (every 1-cm interval) was carried out on the core for subfossil diatom analyses. Samples were digested in $10 \% \mathrm{HCl}$ and $10 \% \mathrm{H}_{2} \mathrm{O}_{2}$ (Battarbee et al., 2001). Aliquots of $400 \mathrm{IL}$ and $800 \mathrm{IL}$ were dried on coverslips and mounted on microscope slides using Naphrax. Approximately 200 valves were counted per slide, which is considered adequate to characterise a diatom community (Bate \& Newall, 1998). Broken valves were counted if the central area was present. Counting was undertaken on a Nikon Eclipse E600 microscope under differential interference contrast using 91000 magnification (oil immersion lens). Diatom taxa were identified following standard texts (e.g. Krammer \& 
4 G. Kattel et al.

4 Lange-Bertalot, 1986, 1988, 1991a,b). The counts for each diatom taxon were expressed as a percentage of the total valves counted. Littoral to planktonic ratios of diatoms were calculated based on the littoral and planktonic (planktonic and facultative planktonic) species counts. Diatom taxa known to inhabit both the plankton and benthos were regarded as opportunistic-facultative planktonic taxa and grouped under planktonic taxa.

\section{Subfossil cladoceran analysis}

High-resolution subsampling (every 1-cm interval) was carried out on the core for subfossil cladoceran analyses. Approximately 3-4 g wet sediment was treated with $100 \mathrm{~mL} 10 \% \mathrm{KOH}$ solution and heated at $60{ }^{\circ} \mathrm{C}$ on a hotplate for at least $45 \mathrm{~min}$. The subsample mixture was sieved through a 38-mm mesh with running tap water. A few drops of safranin were added to stain the remains. Slides were then prepared by pipetting $50 \mathrm{IL}$ of each subsample onto microscopic slides. One hundred or more cladoceran remains (carapaces, headshields, post-abdomen, ephippia and post-abdominal claws) were counted at 4009 magnification. Badly fragmented remains were counted provided that they remained identifiable. The dry mass percentage of each sediment sample was measured to calculate the counted portion of remains present per gram of dry sediment (Kattel et al., 2008). Cladoceran taxa were identified following standard texts (e.g. Shiel \& Dickson, 1995; Szeroczyńska \& Sarmaja-Korjonen, 2007). Littoral to planktonic ratios of cladocerans were calculated based on the littoral and planktonic species counts.

The cladoceran species feeding exclusively in the pelagic habitats, such as Daphnia were grouped as 'Preferentially Pelagic'; species known to switch their feeding habits with changes in food source were regarded as ubiquitous or 'Opportunistic' cladocerans; and those species that feed exclusively on food derived from shoreline and/ or submerged littoral and benthic vegetation were grouped as 'Preferentially Littoral' cladocerans.

\section{Stable isotope of carbon analyses of subfossil cladocerans,}

\section{chironomids and bulk sediment}

To extract sufficient numbers of cladoceran subfossil ephippia and chironomid head capsules, a total of nine subsamples, from depths comprising 0-10, 10-20, 20-30, $30-40,40-50,50-60,60-70,70-80$ and $80-94 \mathrm{~cm}$, were taken from the same core and treated with $10 \% \mathrm{KOH}$, as described previously. Subfossil cladoceran ephippia were sorted into two groups based on the number of embryos in a resting egg. Any ephippium with two embryos was assigned to Daphnia (Vandekerkhove et al., 2004). In contrast, eggs with single embryos are produced mostly by cladocerans such as chydorids (Alona sp., Biapertura sp.) and Bosmina (Gannon \& Stemberger, 1978). For chirono- 5 mids, only five depth strata $(0-10 \mathrm{~cm}, 20-30 \mathrm{~cm}$, $30-40 \mathrm{~cm}, 40-50 \mathrm{~cm}$ and $50-60 \mathrm{~cm}$ ) contained the required number of head capsule. Both cladoceran ephippia and head capsules of chironomids were picked manually using fine forceps and placed separately under a binocular microscope. From each subsample, at least 50-200 ephippia of both groups of Cladocera, and 80 chironomid head capsules (van Hardenbroek, 2010), were needed to achieve a mass of $0.2 \mathrm{mg}$ dry mass. All dry subfossil ephippia and chironomid head capsules were packed into a tin capsule before submitting them for determination of carbon stable isotope composition in SINLAB, New Brunswick, Canada (http://www.unb.ca/ cri/sinlab). SINLAB used both a Costech 4010 Elemental Analyser coupled to the Finnigan Delta Plus XP Mass Spectrometer via the Conflo III and a NC2500 Elemental Analyser coupled to the Finnigan Delta Plus Mass Spectrometer via the Conflo II for $\mathrm{d}^{13} \mathrm{C}$ analysis of subfossil biota. Data were normalised using internal standards that had been calibrated against external standards from the International Atomic Energy Agency (IAEA). The $\mathrm{d}^{13} \mathrm{C}$ standard deviations on external standards were $0.1 \&$. This is close to instrumental error, although these external standards were not 'normalised samples'. The results for the subfossil cladoceran and chironomid samples are from a single analysis of each sample.

Stable carbon isotopes of bulk sediment were analysed in the ANSTO laboratories using an Elemental Analyser (Elementar VarioMICRO) and Isotope Ratio Mass Spectrometer (GV Instruments IsoPrime) on a total of 45 samples ( $2 \mathrm{~cm}$ intervals). After acid treatment using $1 \mathrm{M}$ $\mathrm{HCl}$, rinsing and drying at $60{ }^{\circ} \mathrm{C}$, the samples were loaded into tin capsules and analysed in duplicates, with further replicates if the standard deviations between duplicates exceeded $0.4 \&$. The samples were analysed with both internal and external standards, and the data were normalised using the external standard IAEA C8 with a consensus value of $\mathrm{d}^{13} \mathrm{C}_{\mathrm{V}-\mathrm{PDB}}=-18.31 \&$ (Le Clercq, van der Plicht \& Groning, 1998). The average standard deviation between replicates was $0.2 \&$ for both standards and samples.

\section{Measurement of loss-on-ignition (LOI)}

About $2 \mathrm{~g}$ of wet sediment from each depth sample was heated at $105{ }^{\circ} \mathrm{C}$ in pre-weighted crucibles to determine 
dry mass. The percentage LOI was calculated after placing the crucibles in a furnace (Carbolyte) at $550{ }^{\circ} \mathrm{C}$ for $2 \mathrm{~h}$ (Meyers \& Teranes, 2001).

\section{Numerical analysis}

The diatom and cladoceran stratigraphic diagrams were zoned using CONISS (Grimm, 1987). Taxa were grouped to show the stratigraphy of zonations corresponding with the changes in pelagic, littoral and ubiquitous (pelagic Bosmina plus littoral chydorids) assemblages over time. In each stratigraphy, the littoral:planktonic ratios are also presented. PCA axis 1 in subfossil diatom and cladoceran samples was derived from principal components analysis (PCA), a linear ordination technique in CANOCO 4.5 (ter Braak \& Smilauer, 2002).

\section{Results}

\section{Age model}

The unsupported ${ }^{210} \mathrm{~Pb}$ activities from the Kings Billabong sediment core samples were relatively low, and the chronology should thus be treated with caution. The CIC and CRS models showed close agreement in chronology (Fig. 1a,b). The CRS model suggested that $51 \mathrm{~cm}$ depth is $42 \pm 6$ years old so is dated to $c$. $1969 \pm 6$ AD (Fig. 1b). The CRS model also suggested an increased mass accumulation rate (MAR) in recent years from $0.5 \mathrm{~g}^{-1} \mathrm{~cm}^{2}$ year ${ }^{-1}$ in 1976 to $0.8 \mathrm{~g}^{-1} \mathrm{~cm}^{2}$ year ${ }^{-1}$ in 2009 . These changes in MAR suggest that the CRS model is more reliable. The CIC model should only be used for sediment cores showing constant MARs. The dating below $60 \mathrm{~cm}$ only represents rough estimates as it is derived from a simple extrapolation based on the sedimentation rates calculated at $60 \mathrm{~cm}\left(\mathrm{MAR}=c .0 .6 \mathrm{~g}^{-1} \mathrm{~cm}^{2}\right.$ year $\left.{ }^{-1}\right)$, and should therefore be treated with caution.

\section{Subfossil diatom stratigraphy}

The L:P ratios of diatoms also revealed that the basal zone (Zone $1-70-94 \mathrm{~cm}$, possibly prior to the 1930s) of the diatom stratigraphy is dominated by benthic and periphytic taxa such as Epithemia adnata and Cocconeis placentula (Fig. 2). However, there was a temporary large peak in the total planktonic assemblage at $90 \mathrm{~cm}$ (Fig. 2). Epiphytic taxa decreased gradually from the bottom of the core to the top (Fig. 2). Facultative planktonic taxa, such as Staurosira construens var. construens and Staurosira construens $\mathrm{f}$. venter, began to increase from $70 \mathrm{~cm}$ to $35 \mathrm{~cm}$ (Zone 2 and $3-c .1985$ AD), showing the transition from benthic, clear-water conditions to a turbid water regime (Fig. 2). Facultative planktonic species, particularly Pseudostaurosira brevistriata, S. construens var. construens [Ehrenberg (Hustedt)] and S. construens f. venter [Ehrenberg (Hustedt)], continued to dominate the system until the upper section (Zone $4 \& 5$ ) of the core (Fig. 2).

\section{Subfossil cladocerans stratigraphy}

Littoral to planktonic (L:P) ratios revealed that the basal zone (Zone 1 - 70-94 cm, possibly prior to 1930s) of the cladoceran stratigraphy is dominated by littoral species (Fig. 3). The littoral taxon Dunhevedia crassa was the only littoral species to influence the total littoral assemblage and the cluster in CONISS (Fig. 3). Above this zone (Zone 2), the cladoceran assemblage was associated with more ubiquitous or opportunistic species such as Alona guttata and Bosmina meridionalis with a gradual decline in $\mathrm{L} / \mathrm{P}$ ratios (Fig. 3). Ratios did not change further from $40 \mathrm{~cm}$ and upwards. Several opportunistic species, including B. meridionalis, Chydrous sphaericus, Alona quadrangularis and Biapertura longispina, continued to dominate the cladoceran community. Mostly, post-abdominal
Fig. 1 (a) Unsupported ${ }^{210} \mathrm{~Pb}$ activity plotted against depth, (b) sediment age estimated from CIC and CRS models plotted against depth.
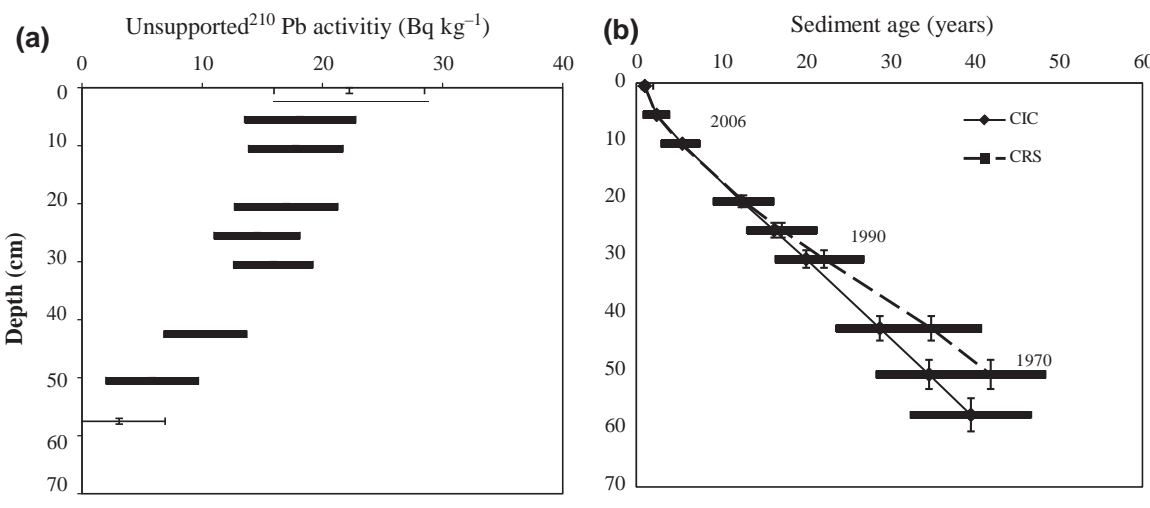


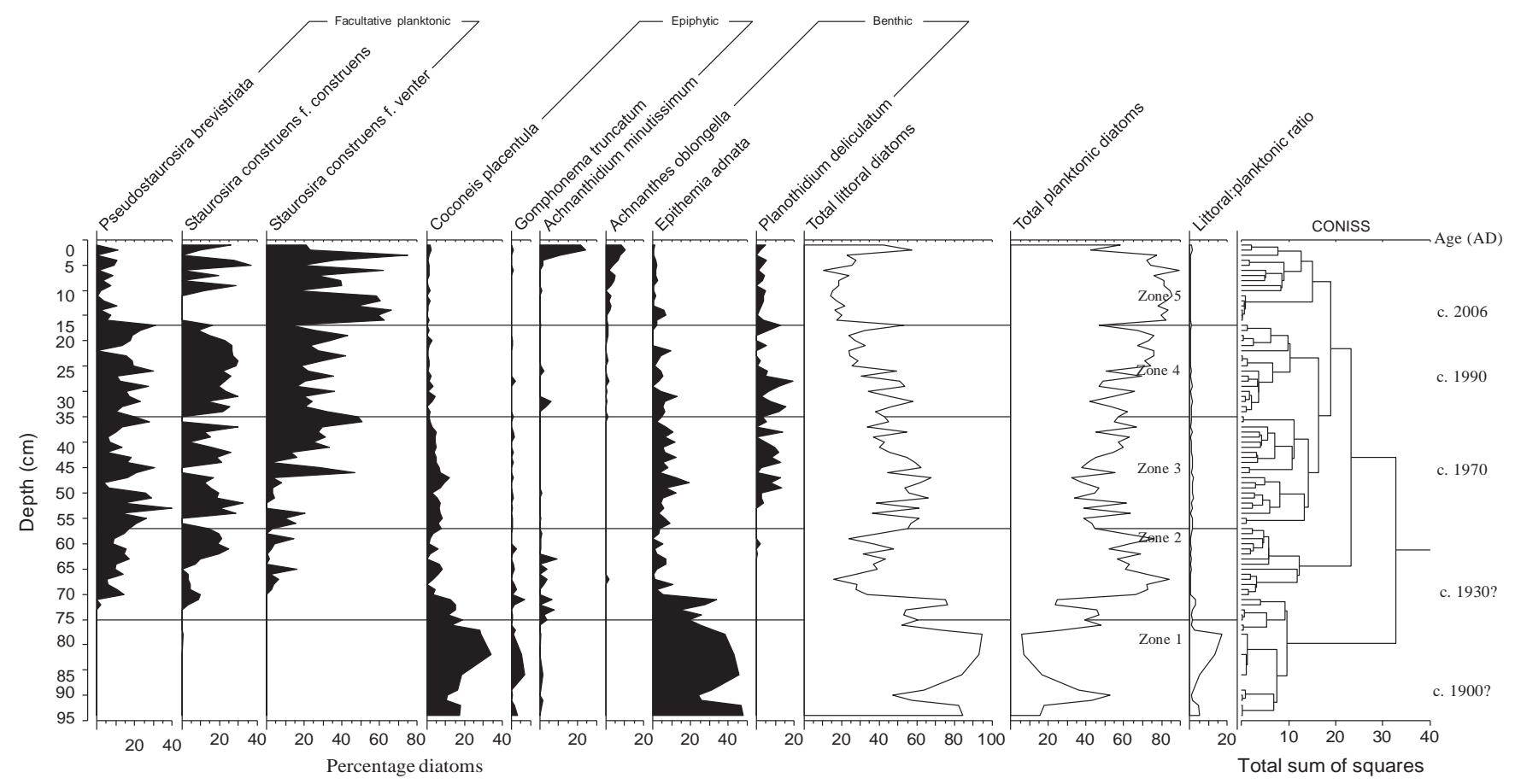

Fig. 2 Diatoms that indicate major food web change in Kings Billabong. The overall assemblage of diatoms was classified using the program CONISS. L:P ratios were calculated on the basis of total littoral diatoms divided by total planktonic (planktonic and facultative planktonic) diatom concentrations (individuals).

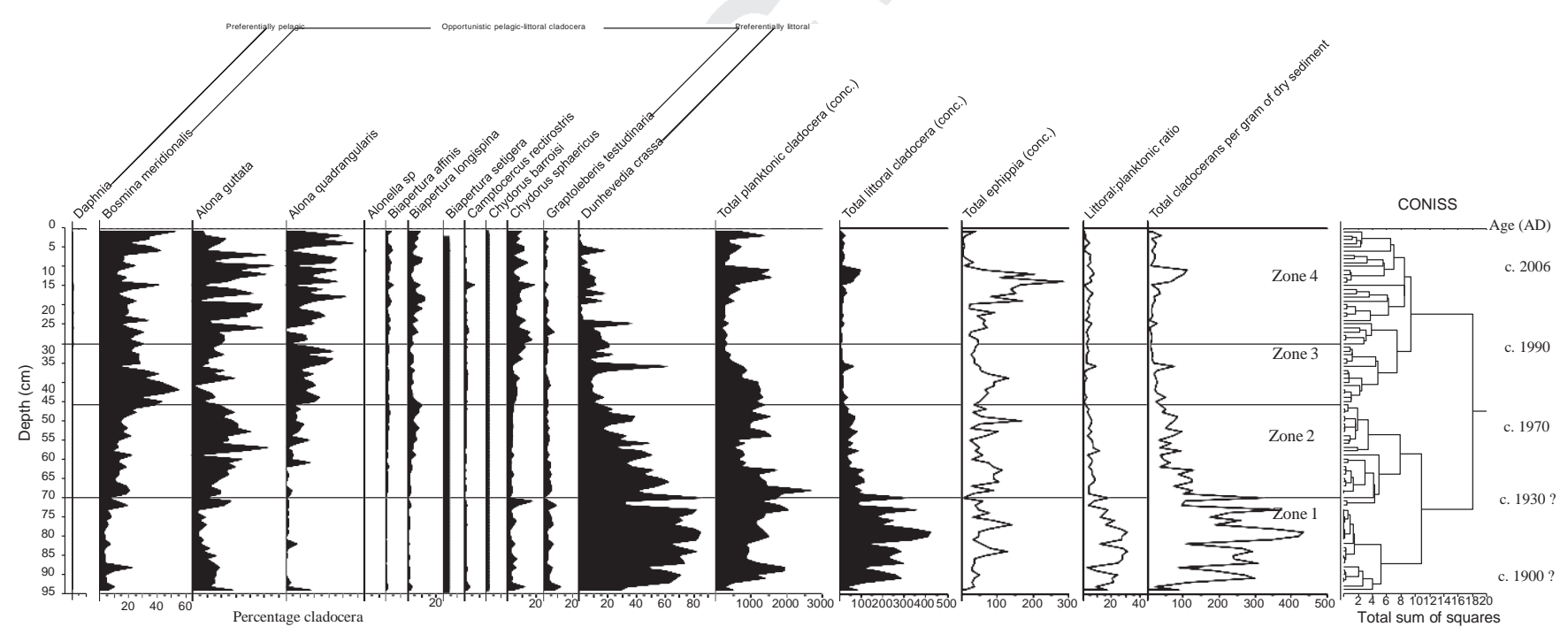

Fig. 3 Cladocerans that indicate major food web change in Kings Billabong. Based on previous studies, and their commonalities in lakes, cladoceran species present in Kings Billabong were grouped as 'Preferentially Pelagic', 'Opportunistic' and 'Preferentially Littoral'. The overall assemblage of cladocerans was classified using the program CONISS. L:P ratios were calculated on the basis of total littoral cladocerans divided by total planktonic cladocerans.

claws and ephippia of Daphnia, the 'preferentially' pelagic cladocerans, are preserved in sediment. From $40 \mathrm{~cm}$ (Zone 3 \& 4), more Daphnia remains were recorded than non-pelagic remains (Fig. 3). $\mathrm{d}^{13} \mathrm{C}$ values in bulk sediments and percentage LOI

The LOI and $d^{13} \mathrm{C}$ values of the bulk sediment samples of the entire core were strongly correlated $\left(r^{2}=0.78\right.$, 
$P=0.0001)$. This reflects the changes in the carbon isotopic composition of the sediment OM (Fig. 4). The $d^{13} \mathrm{C}$ values of sedimentary carbon show a systematic depletion in ${ }^{13} \mathrm{C}$ of $c .3 .2 \&$ up-core (Fig. 4). The most enriched $\mathrm{d}^{13} \mathrm{C}$ values were recorded in sediment deposited prior to the $1920 \mathrm{~s}(70 \mathrm{~cm})$ with values ranging from $-23.9 \&$ to $-22.0 \&$ (Fig. 4). During this period, the percentage LOI was below $30 \%$ (Fig. 4). The period before the 1920 s coincided with high littoral:planktonic ratios, which is also reflected in the PCA axis 1 of the cladoceran and diatom assemblages (Fig. 4). Following 1990, the $d^{13} \mathrm{C}$ values in the sediment depleted further to $-25.6 \&$, and the LOI declined to values as low as $22.7 \%$ (Fig. 4 ).

$\mathrm{d}^{13} \mathrm{C}$ values of chironomid head capsules

Values of chironomid head capsules were obtained for the years 1955-2011 at a time resolution of c. 15 years (Fig. 4). The $d^{13} \mathrm{C}$ values showed a relatively similar trend to that of $d^{13} \mathrm{C}$ values of bulk sediment samples, reflecting their dependency on profundal-sediment carbon sources (Fig. 4). The most enriched $d^{13} \mathrm{C}$ value (-24.0\&) of chironomids was recorded between c. 1940 and c. 1955 (Fig. 4). During the period 1955-1970, the head capsule $\mathrm{d}^{13} \mathrm{C}$ values decreased to $-26.0 \&$ and became enriched again to -24.8\& during 1970-1985 (Fig. 2). Between 1985 and 1990, the head capsule $\mathrm{d}^{13} \mathrm{C}$ values declined to -25.73\&. Measurement of the $d^{13} \mathrm{C}$ values of head capsules, during 1990-2000, was not successful; however, there was an enrichment trend $(-24,69 \&)$ in the head capsules between 2000 and 2006 (Fig. 4).

The $\mathrm{d}^{13} \mathrm{C}$ values of pelagic Daphnia and ubiquitous cladocerans

The $\mathrm{d}^{13} \mathrm{C}$ values of ubiquitous (Bosmina, Alona) and pelagic (Daphnia) cladocerans were obtained from nine sections, with a resolution of about 15 years, covering the period of mare thap 190 varears from 1900 to 2006 (Figros)

13

$-29.4 \&$ to $-24.5 \&$, while the $\mathrm{d}^{13} \mathrm{C}$ values of pelagic Daphnia ranged from $-29.8 \&$ to $-23.2 \&$ (Fig. 4). The $\mathrm{d}^{13} \mathrm{C}$ values of ubiquitous and pelagic cladocerans were lower than those of bulk sediment and chironomid head capsules. Such differences between the $\mathrm{d}^{13} \mathrm{C}$ values of consumers and that of bulk organic matter are rather typical. They are attributed to feeding selectivity or preferential assimilation of algae or fresh material within seston or sediment that are usually ${ }^{13} \mathrm{C}$ depleted as compared to the bulk organic matter (Del Giorgio \&
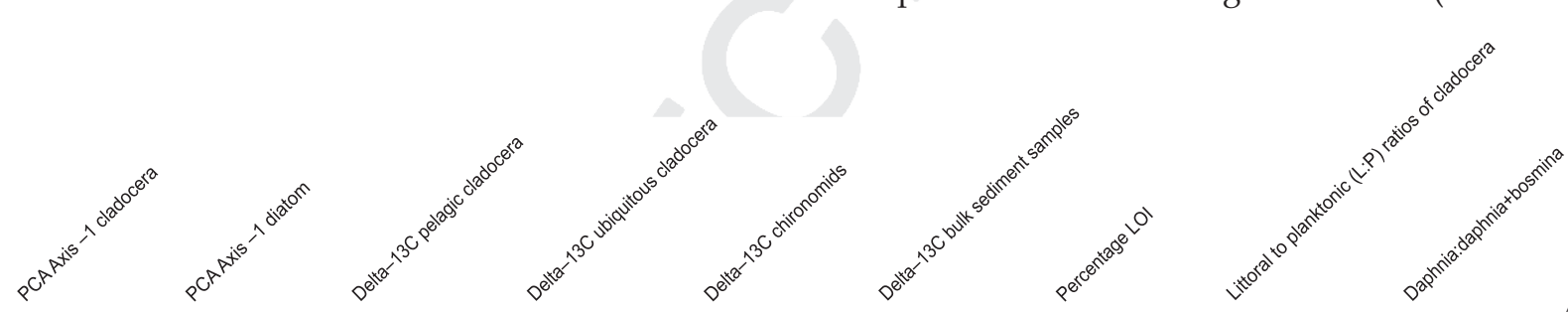

Age (AD)

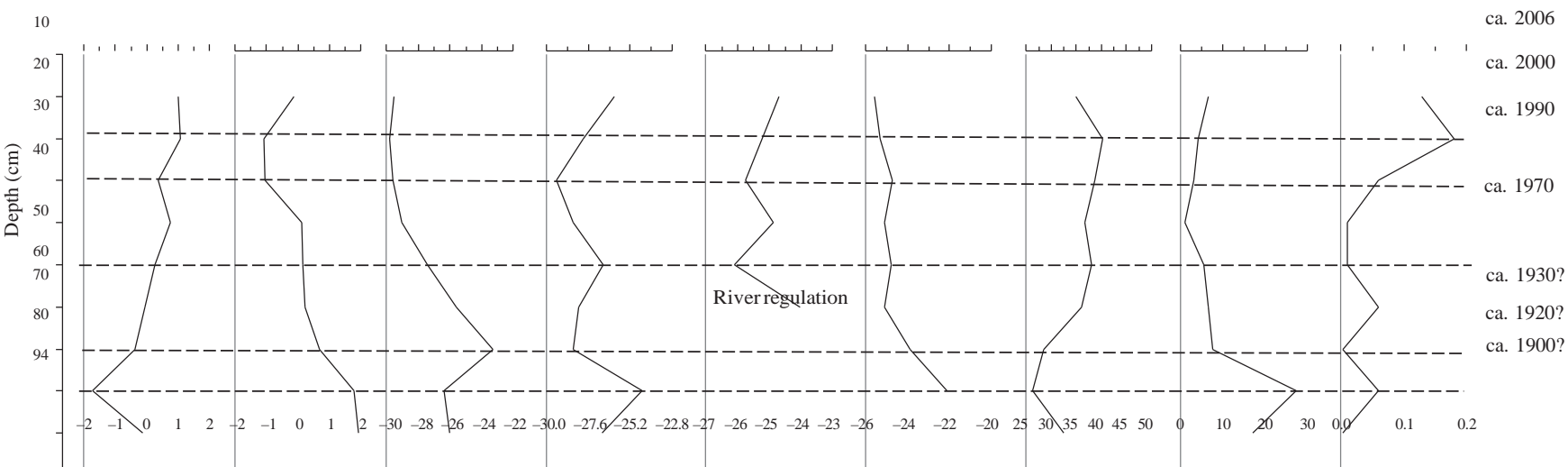

Fig. 4 The'stable isotope values of carbon '(d ${ }^{13} \mathrm{C}$ ) in 'subfossiT pelagic Daphnia, ubiquitous Bosmin'a and'Alona sp.,'and chironomids, and the bulk sediment samples are compared to changes in the PCA axis 1 of the cladoceran and diatom assemblages and the percentage LOI of the sediments samples collected from Kings Billabong. The transition of the ecosystem from pre- to post-human impacts is reflected in the littoral:planktonic ratio of cladocerans during the late 1920s, and changes in predation pressure in the Daphnia:Daphnia+Bosmina ratio in 1990s and 2000s. The stable isotope values for carbon in subfossil cladocerans and chironomids were calculated at 10-cm resolution while, for bulk sediment samples, at $2-\mathrm{cm}$ resolution. Age is based on ${ }^{210} \mathrm{~Pb}$ dating. 


\section{G. Kattel et al.}

France, 1996; Grey \& Deines, 2005). Depositional and diagenetic processes only slightly affect the carbon isotope composition of cladoceran subfossil remains (changes by <1\&; Perga, 2011) and may not account for observed patterns. However, overall, the $\mathrm{d}^{13} \mathrm{C}$ of Daphnia followed the same trend as bulk sediment $d^{13} \mathrm{C}$ and such a common trend mirrored temporal changes of $d^{13} \mathrm{C}$ of the autochthonous primary producers. Prior to about 1920 (below $80 \mathrm{~cm}$ ), Kings Billabong was dominated by littoral-submerged vegetation, as indicated by PCA axes 1 for cladocerans and diatoms and the littoral:planktonic ratios (Fig. 4). Both ubiquitous and pelagic consumers showed relatively enriched $d^{13} \mathrm{C}$ values, with differences of about $1-1.5 \&$ in between them. However, during the time of river regulation in c. 1927, and immediately after this period $(80-70 \mathrm{~cm})$, the $\mathrm{d}^{13} \mathrm{C}$ values of pelagic Daphnia became as high as $-23 \&$, while the $d^{13} \mathrm{C}$ values of ubiquitous cladocerans depleted steadily (Fig. 4). This period was also reflected in PCA axis 1 scores for cladocerans. The strong differences in $d^{13} \mathrm{C}$ values between the two cladoceran groups, and for PCA axis 1 scores at the initial transition phase from pre- to post-river regulation, indicate a clear separation in their trophic niche/ micro-habitat preference. By 1970, as the system became more productive, with planktonic flora and fauna being dominant (see Figs. $3 \& 4$ ), the $d^{13} \mathrm{C}$ values of both ubiquitous and pelagic cladocerans began to converge, showing the uptake of similar carbon sources (Fig. 4). However, by 1990 and subsequently, the $d^{13} \mathrm{C}$ values of ubiquitous and pelagic cladocerans diverged. Daphnia $\mathrm{d}^{13} \mathrm{C}$ remained at similar low values, but those of ubiquitous cladocerans increased by more than $3.5 \&$ and the Daphnia; Daphnia+Bosmina ratio increased (Fig. 4). These patterns were opposite to those observed immediately around the time of, and after, river regulation $(80 \mathrm{~cm})$ as the $d^{13} \mathrm{C}$ values for Daphnia were enriched compared with the depleted $\mathrm{d}^{13} \mathrm{C}$ values of ubiquitous cladocerans (Fig. 4).

\section{Discussion}

Our study, based on analyses of sediment accumulation, subfossil data and stable isotopes, revealed a significant transition in the Kings Billabong ecosystem following river regulation. Within the past 50-year time span, the sediment accumulation rates increased. By 2006, the rate was high (c. $1 \mathrm{~g} \mathrm{~cm}^{-2}$ year $^{-1}$ ) and similar to other billabongs in the region, suggesting widespread disturbances of catchments by humans (e.g. Gell et al., 2009). Previous studies in upstream River Murray billabongs suggest that the period of catchment disturbance, ero- sion and input of allogenic minerals to lakes coincided with the loss of submerged vegetation (e.g. Reid et al., 2007). Our findings give further evidence of this. Except for a brief peak in planktonic and facultatively planktonic diatoms (possibly due to the 1906 flood), the subfossil assemblages of cladocerans and diatoms, and their littoral to planktonic ratios, clearly indicate that the wetland was densely covered by submerged macrophytes pre- c. $1930 \mathrm{AD}$ (below $70 \mathrm{~cm}$ ) when human disturbance was low. In the absence of river regulation, submerged macrophyte beds are most likely to have played a key role in maintaining a clear-water littoral-benthic dominated system, stabilising sediments, reducing nutrient recycling for phytoplankton and, ultimately, enhancing zooplankton (e.g. Daphnia) grazing on phytoplankton, as seen in shallow lakes elsewhere (e.g. Moss, 1990; Scheffer et al., 1993; Jeppesen et al., 1998). However, following human-induced disturbance, including deforestation, agriculture and river regulation (Kingsford, 2000), the littoral and benthic assemblages of subfossil cladocerans (Dunhevedia crassa) and diatoms (Epithemia adnata, Coconeis placentula) declined substantially, with a reciprocal increase in ubiquitous cladocerans (Bosmina meridionalis, Alona guttata, Biapertura longispina) and facultatively planktonic diatoms, including Staurosira construens f. construens Staurosira construens f. venter (above 75$70 \mathrm{~cm}$ ). These opportunistic diatom species are now common in the shallow floodplain lakes of the southeast Australian region (Gell, Sluiter \& Fluin, 2002; Gell et al., 2007; Fluin, Tibby \& Gell, 2010; Grundell et al., 2012) and reflect turbid conditions and simplified habitat. The changes in littoral-benthic floral and faunal communities suggest a gradual, rather than an abrupt, loss of submerged plants.

The $\mathrm{d}^{13} \mathrm{C}$ signatures of key primary consumers (chironomids, pelagic Daphnia and ubiquitous cladocerans), as well as in sediment organic matter, provide further evidence of a shift in tropic structure in the billabong. It is well established that $d^{13} \mathrm{C}$ values at the base of littoral-benthic food webs are usually enriched in ${ }^{13} \mathrm{C}$ (less negative $d^{13} \mathrm{C}$ ) than those at the base of pelagic food webs (Post, 2002), due to differential fractionation of inorganic carbon taken up by primary producers (France, 1995). Local dissolved inorganic carbon (DIC) availability is controlled by a combination of boundary layer thickness and the uptake rate of primary producers relative to the DIC diffusion rate into the boundary layer (Post, 2002). Normally, littoral producers may experience less turbulence and have a thicker boundary layer than pelagic producers (France, 1995); they are therefore more $\mathrm{CO}_{2}$ limited, fractionate less DIC during 
uptake and are enriched in ${ }^{13} \mathrm{C}$ compared to pelagic zone producers. Moreover, and accordingly, percentage LOI, bulk sediment ${ }^{13} \mathrm{C}$, and ubiquitous cladoceran and chironomid ${ }^{13} \mathrm{C}$ were all enriched immediately after the wetland was inundated in the 1930s (Fig. 4). Temporal changes in phytoplankton with depleted ${ }^{13} \mathrm{C}$ were apparent as suggested by the declining $\mathrm{d}^{13} \mathrm{C}$ values in Daphnia and sediment bulk organic matter (Fig. 4).

Prior to river regulation (1900-1930), there was only a small difference (about $1 \&$ ) in $\mathrm{d}^{13} \mathrm{C}$ values between pelagic Daphnia and ubiquitous cladocerans, indicating the predominant reliance of both consumer groups on littoral-benthic derived carbon sources, probably reflecting the widespread distribution of submerged macrophytes in the billabongs. However, around the time of river regulation (after $1927 \mathrm{AD}$ ), the $\mathrm{d}^{13} \mathrm{C}$ values in pelagic Daphnia became enriched to $-23.2 \&$, while in ubiquitous cladocerans, the $\mathrm{d}^{13} \mathrm{C}$ values depleted to $-28.4 \&$ (Fig. 4). This coincided with low littoral:planktonic ratios and high PCA axis 1 sample scores for cladocerans, suggesting expansion of the pelagic habitat (Fig. 4). Although this is based on a single data-point, results suggest that the contribution of littoral-benthic-derived carbon sources to the food web became substantially lower during this period, except for Daphnia being $7 \&$ more enriched than the ubiquitous cladocerans. Jones \& Waldron (2003) suggested that an increased density of predatory fish in shallow U.K. lakes can affect the invertebrate prey communities via two different mechanisms: zooplankton (Daphnia) would spend more time among the plants with potential access to periphyton during the day, whilst other invertebrates would take refuge in the benthos during the day by leaving the periphyton. Such a behavioural phenomenon in invertebrate migrations is significant in the context of ${ }^{13} \mathrm{C}$ enrichment. Periphyton can have a substantially thicker boundary layer and a correspondingly reduced supply of $\mathrm{CO}_{2}$, with possible enriched ${ }^{13} \mathrm{C}$, than the free floating phytoplankton (Hecky \& Hesslein, 1995). In Kings Billabong, the largebodied cladocerans (Daphnia) may have sought refuge in the periphyton-dominated littoral vegetation during the day, due to a high risk of fish predation in the pelagic zone, leading to this ${ }^{13} \mathrm{C}$ enrichment. Such a behavioural shift is also well known from other northern temperate lakes (Lauridsen et al., 1996; Jeppesen et al., 1998).

Since the 1970s until the 1990s, however, the $d^{13} \mathrm{C}$ values in both pelagic Daphnia and ubiquitous cladocerans depleted substantially and converged, indicating exploitation of the same food, presumably following a further reduction in the littoral area and the loss of refuge areas for Daphnia. Increased turbidity also reduces the hunting ability of fish (Vinyard \& O'Brien, 1976). Depletion of ${ }^{13} \mathrm{C}$ in pelagic Daphnia during 1990-2006, and reciprocal enrichment in ubiquitous cladocerans, indicates some major changes in the feeding patterns of these consumers (Daphnia being more pelagic and ubiquitous cladocerans more littoral-benthic) and subsequent changes in trophic pathways at the base of the food web in Kings Billabong in recent decades. Moreover, the Daphnia: Daphnia + Bosmina ratio suggests reduced fish predation (e.g. Jeppesen et al., 2003). Apparently, fish predation became less strong during this period, allowing Daphnia to stay more in the pelagic zone and thereby forcing ubiquitous cladocerans to be more littoral-benthic. The prolonged drought during the 2000s in north-west Victoria could have altered the effect of fish predation on Daphnia (e.g. Matthews \& Matthews, 2003). However, it must be emphasised that that the depletion of ${ }^{13} \mathrm{C}$ in pelagic Daphnia at the top of the core is based on only one sample and therefore should be interpreted with caution. A lower water volume due to drought may also have resulted in slightly increased submerged macrophyte abundance, as indicated by the increased density of epiphytic diatoms (Achnanthidium minutissimum) in the Billabong (Fig. 2).

Chironomid head capsules gradually became more depleted in ${ }^{13} \mathrm{C}$ at the time of river regulation but were less affected by the regime shift than the cladocerans. This may reflect the fact that the remains of cladocerans in lake sediment are from individuals, feeding in the pelagic or in the littoral zone, having contrasting $\mathrm{d}^{13} \mathrm{C}$ values, and that the $d^{13} \mathrm{C}$ also varies seasonally, while most chironomids feed on a mixture of food in the sediment, showing less seasonality and living longer (Van Hardenbroek et al., 2010). Accordingly, the $d^{13} \mathrm{C}$ values in chironomid head capsules followed those of the bulk sediment samples (Fig. 4). Chironomid head capsules were enriched by about $6 \&$ compared to pelagic Daphnia and were about $4 \&$ higher than that of the ubiquitous cladocerans. As for cladocerans, isotopic fractionation between chironomid exuvia and their food sources are small $(0-1 \&)$ and cannot be responsible for observed isotope differences between the two taxa (Frossard et al., 2013). In the River Murray system, depleted $\mathrm{d}^{13} \mathrm{C}$ (as low as $\mathrm{d}^{13} \mathrm{C}=-54.7 \&$ ) values have been measured in riparian leaf litter (Bunn et al., 2003) and $d^{13} \mathrm{C}$ values as low as $-64 \&$ have been measured in chironomids elsewhere (Jones et al., 2008). In deeper lakes in Europe, methane oxidising bacteria in the sedimentwater interface have substantially depleted ${ }^{13} \mathrm{C}$ carbon values (Segers, 1998). However, the $\mathrm{d}^{13} \mathrm{C}$ values of head capsules in Kings Billabong are greatly enriched relative 
to those of the riparian leaf litter, more enriched than the algae as judged from the cladoceran $d^{13} \mathrm{C}$ data but rather similar to the values of the biota measured prior to river regulation. Apparently the carbon sources for chironomids are still, to some extent, derived from benthic algae and macrophyte debris may have accumulated prior to river regulation or wetland plant remains may have been washed into the billabong. In the Mississippi River system (U.S.A.), the $\mathrm{d}^{13} \mathrm{C}$ values in decaying aquatic vegetation were found to be higher $(-27 \&$ to $-20 \&)$ than those of terrestrial plants $(-32 \&$ to $22 \&)$ in the river (Kendall, Silva \& Kelly, 2001).

In conclusion, the integration of palaeoecology and stable isotope analyses of selected subfossils in Kings Billabong has offered a better understanding of ecological succession over temporal scales in a regulated floodplain wetland in south-east Australia. The succession of pelagic-benthic primary producers (e.g. diatoms) and consumers (chironomids and cladocerans) over the past century provides evidence of an ecological transition caused by human-induced disturbance, while the $d^{13} \mathrm{C}$ signatures of subfossil consumers reflect the disturbance through the carbon energy flow. The collapse of the benthic-littoral food web following river regulation and the depleted ${ }^{13} \mathrm{C}$ values in pelagic Daphnia, reflect a possible shift in trophic pathways and in ecosystem structure.

Our results demonstrate that high-resolution sediment samples show long-term changes in carbon flows in subfossil pelagic and benthic consumers and ecosystem regime shifts. Replication of such studies in other wetlands would be valuable in providing landscape level information about trophic dynamics, regime shifts and wetland resilience in response to varying disturbance regimes, including river regulation, nutrient loading, species invasion and climate change.

\section{Acknowledgments}

The study was supported by funding from AINSE (AINSEGRA \#11087) and the Federation University Australia's CRN program (\# 160186 \& 160157) to GK and by a Visiting Professor Grant from the University of Savoie to MP to support GK's travel to France in 2013. GK's travel to Denmark in 2014 to visit EJ, and part of this research, was also supported by the MARS project (Managing Aquatic ecosystems and water Resources under multiple Stress) funded under the 7th EU Framework Programme, Theme 6 (Environment including Climate Change), Contract No.: 603378 (http://www.marsproject.eu), 'CLEAR' (a Villum Kann Rasmussen Centre of Excellence project), CRES and CIRCE to EJ. Labora- tory support was provided by ANSTO, Faculty of Science \& Technology (Federation University Australia), Geochemistry Lab (Melbourne University) and SINLAB (Canada). The field work assistance was supported by Faculty of Science \& Technology and CRN Competitive Grant \# 160157 to GK. We thank Anne Mette Poulsen for valuable editorial comments. Finally, we would like to thank John Smol and an anonymous reviewer for their constructive comments on the manuscript.

\section{References}

Appleby P.G. (2001) Chronostratigraphic techniques in recent sediments. In Tracking Environmental Change Using Lake Sediments, Volume 1: Basin Analysis, Coring and Chronological Techniques. (Eds Last W.M. \& Smol J.P.), pp. 171-203. Kluwer Academic Publishers, Dordrecht.

Bate N. \& Newall P. (1998) Techniques in the use of diatoms in water quality assessment: how many valves? In Proceedings of the 15th International Diatom Symposium. (John J. ed), pp. 153-160. Curtin University of Technology, Perth.

Battarbee R.W., Jones V.J., Flower R.J., Cameron N.G., Bennion H., Carvalho L. et al. (2001) Diatoms. In Tracking Environmental Change Using Lake Sediments. Volume 3: Terrestrial, Algal, and Siliceous Indicators. (Eds Smol J.P., Birks H.J.B. \& Last W.M.), pp. 155-202. Kluwer Academic Publishers, Drodrecht.

ter Braak C.J.F. \& Smilauer P. (2002) CANOCO reference manual and CanoDraw for Window's User's guide: Software for Canonical Community Ordination (Version 4.5), pp. 500. Microcomputer Power, Ithaca, NY.

Bunn S.E., Davis P.M. \& Winning M.W. (2003) Sources of organic carbon supporting the food web of an arid zone floodplain river. Freshwater Biology, 48, 619-635.

Burford M.A., Cook A.J., Fellows C.S., Balcombe S.R. \& Bunn S.E. (2008) Sources of carbon fuelling production in an arid floodplain river. Marine and Freshwater Research, $59,224-234$.

Del Giorgio P.A. \& France R.L. (1996) Ecosystem-specific patterns in the relationship between zooplankton and POM or microplankton \& \#x03B4;13C. Limnology \& Oceanography, 41, 359-365.

DeMott W.R. (1989) The role of competition in zooplankton successions. In Plankton Ecology Succession in plankton communities. (Sommer U. ed), pp. 195-252. Springer, Berlin, Heidelberg, New York.

Fluin J., Tibby J. \& Gell P. (2010) The palaeolimnological record from lake Cullulleraine, lower Murray River (south-east Australia): implications for understanding riverine histories. Journal of Paleolimnology, 43, 309-322.

France R.L. (1995) Differentiation between littoral and pelagic food webs in lakes using carbon isotopes. Limnology E Oceanography, 40, 1310-1313. 
Francis T.B., Schindler D.E., Holtgrieve G.W., Larson E.R., Scheuerell M.D., Semmens B.X. et al. (2011) Habitat structure determines resource use by zooplankton in temperate lakes. Ecology Letters, 14, 364-372.

Frazier P. \& Page K. (2006) The effect of river regulation on floodplain wetland inundation, Murrumbidgee River, Australia. Marine and Freshwater Research, 57, 133-141.

Frossard V., Belle S., Verneaux V., Millet L. \& Magny M. (2013) A study of the \& \#x03B4;13C offset between implications for palaeoecology. Journal of Paleolimnology, 50, 379-386.

Frossard V., Verneaux V., Millet L., Jenny J.-P., Arnaud F., Magny M. et al. (2014) Reconstructing long-term changes (150 years) in the carbon cycle of a clear-water lake based on the stable carbon isotope composition $\left(d^{13} \mathrm{C}\right)$ of chironomid and cladoceran subfossil remains. Freshwater Biology, 59, 789-802.

Gannon J.E. \& Stemberger R.S. (1978) Zooplankton (especially crustaceans and rotifers) as indicators of water quality. Transactions of the American Microscopical Society, 97, 16-35.

Gehrke P.C. \& Harris J.H. (2000) Large-scale patterns in species richness and composition of temperate riverine fish communities, south-eastern Australia. Marine and Freshwater Research, 51, 165-182.

Gell P.A., Fluin J., Tibby J., Hancock G., Harrison J., Zawadzki A. et al. (2009) Anthropogenic acceleration of sediment accretion in lowland floodplain wetlands, Murray Darling Basin, Australia. Geomorphology, 108, 122-126.

Gell P.A., Sluiter I.R. \& Fluin J. (2002) Seasonal \& interannual variations in diatom assemblages in Murray Darling River connected wetlands in north-west Victoria, Australia. Marine and Freshwater Research, 53, 981-992.

Gell P.A. Tibby T., Little F. Baldwin D. \& Hancock G. (2007) The impact' of regulation and salinization on flood; aon lakes: the lower river Murray, Australia. Hydrobiologia, 591, 135-146.

Gippel C.J. \& Blackham D. (2002) Review of Environmental Impacts of Flow Regulation and Other Water Resource Developments in the River Murray and Lower Darling River System. Final Report for the Murray Darling Basin Commission, Canberra.

Grey J. \& Deines P. (2005) Differential assimilation of methanotrophic and chemoautotrophic bacteria by lake chironomid larvae. Aquatic Microbial Ecology, 40, 61-66.

Grimm E. (1987) Coniss: a Fortran 77 Program for Stratigraphically Constrained Cluster Analysis by the method of incremental sum of squares. Computers \& Geosciences, 13, 13-35.

Grundell R., Gell P., Mills K. \& Zawadzki A. (2012) Interaction between a river and its wetland: evidence from the Murray River for spatial variability in diatom and radioisotope records. Journal of Paleolimnology, 47, 205-219.
Harrison J., Heijnis H. \& Caprarelli G. (2003) Historical pollution variability from abandoned mine sites, Greater Blue Mountains World Heritage Area, New South Wales, Australia. Environmental Geology, 43, 680-687.

Hecky R.E. \& Hesslein R.H. (1995) Contributions of benthic algae to lake food webs as revealed by stable isotope analyses. Journal of the North American Benthological Society, 14, 6312-6653.

Jeppesen E., Jensen J.P., Lauridsen T.L., Amsinck S.L., Christoffersen K. \& Mitchell S.F. (2003) Sub-fossils in the surface sediment as proxies for community structure and dynamics of zooplankton in lakes: a study of 150 lakes from Denmark, New Zealand, the Faroe Islands and Greenland. Hydrobiologia, 491, 321-330.

Jeppesen E., Lauridsen T.L., Kairesalo T. \& Perrow M.R. (1998) Impact of submerged macrophytes on fish-zooplankton interactions in lakes. The Structuring Role of Submerged Macrophytes in Lakes. Ecological Studies Series, 131, 91-114.

Jeppesen E., Leavitt P., De Meester L. \& Jensen J.P. (2001) Functional ecology and palaeolimnology: using cladoceran remains to reconstruct anthropogenic impact. Trends in Ecology and Evolution, 16, 191-198.

Jones J.I. \& Waldron S. (2003) Combined stable isotope and gut contents analysis of food webs in plan-dominated, shallow lakes. Freshwater Biology, 48, 1396-1407.

Jones R.I., Carter C.E., Kelly A., Ward S., Kelly D.J. \& Grey J. (2008) Widespread contribution of methane-cycle bacteria to the diets of lake profundal chironomid larvae. Ecology, 89, 857-864.

Kattel G.R., Battarbee R.W., Mackay A.W. \& Birks H.J.B. (2008) Recent ecological change in remote mountain loch: an evaluation of cladocera-based temperature transfer function. Palaeogeography, Palaeoecology, Palaeooceanography, 259, 51-76.

Kattel G.R., Dong X. \& Yang X. (2014) Cladoceran-inferred ecological and hydrological changes of two floodplain wetlands in two large river systems, the Murray (Australia) and Yangtze (China). In: Proceedings of the AustraliaChina Wetland Network Research Partnership Symposium (Ed G. Kattel ), March 23-28, Nanjing, China, pp. 125, Collaborative Research Network, Federation University Australia, ????.

Kendall C., Silva S.R. \& Kelly V.J. (2001) Carbon and nitrogen isotopic compositions of particulate organic matter in four large river systems across the United States. Hydrological Processes, 15, 1301-1346.

King A.J., Humphries P. \& Lake P.S. (2003) Fish recruitment on floodplains: the roles of patterns of flooding and life history characteristics. Canadian Journal of Fisheries and Aquatic Sciences, 60, 773-786.

Kingsford R. (2000) Ecological impacts of dams, water diversions and river management on floodplain wetlands in Australia. Austral Ecology, 25, 109-127. 
Krammer K. \& Lange-Bertalot H. (1986) Susswasserflora von Mitteleuropa. Bacillariophyceae, pp. 876, Teil i: Naviculaceae. Gustav Fischer Verlag, Stuttgart.

Krammer K. \& Lange-Bertalot H.. (1988) Susswasserflora von Mitteleuropa. Bacillariophyceae, pp. 576, Teil ii: Bacillariaceae, Epithemiaceae, Surirellaceae. Gustav Fischer Verlag, Stuttgart.

Krammer K. \& Lange-Bertalot H. (1991a) Susswasserflora von Mitteleuropa. Bacillariophyceae, pp. 596, Teil iii: Centrales, Fragilariaceae, Eunotiaceae. Gustav Fischer Verlag, Stuttgart.

Krammer K. \& Lange-Bertalot H. (1991b) Susswasserflora von Mitteleuropa. Bacillariophyceae, pp. 437, Teil iv: Ach7 nanthaceae. Gustav Fischer Verlag, Stuttgart.

Lampert W. (1989) The adaptive significance of diel vertical migration of zooplankton. Functional Ecology, 3, 21-27.

Lauridsen T.L., Pedersen L.J., Jeppesen E. \& Søndergaard M. (1996) The importance of macrophyte bed size for cladoceran composition and horizontal migration in a shallow lake. Journal of Plankton Research, 12, 2283-2294.

Le Clercq M., van der Plicht J. \& Groning M. (1998) In: New ${ }^{14} \mathrm{C}$ reference materials with activities of 15 and $50 \mathrm{p} \mathrm{MC}$ (Eds W.G. Mook \& J. van der Plicht), Proceedings of the 16th International 14C Conference, Radiocarbon, 40, 295297.

Matthews W.J. \& Matthews E.M. (2003) Effects of drought on fish across axes of space, time and ecological complexity. Freshwater Biology, 48, 1232-1253.

McBride T.F. (1898) Letters from Victorian Pioneers. Published for the Trustees of the Public Library, Victoria. Republished in 1983 with foreword from Helen Vellacott, by Lloyd O'Neil, South Yarra, Victoria.

MCMA (2006) Mallee River Health Strategy. Mallee Catchment Management Authority, Mildura.

Meyers P.A. \& Teranes J.L. (2001) Sediment organic matter. In Tracking Environmental Change Using Lake Sediments. Volume 2: Physical and Geochemical Methods. (Eds Smol J.P. \& Last W.M.), pp. 239-269. Kluwer Academic Publishers, Drodrecht.

Moss B. (1990) Engineering and biological approaches to the restoration from eutrophication of shallow lakes in which aquatic plant communities are important components. Developments in Hydrobiology, 61, 367-377.

Nielsen D.L., Smith F.J., Hillman T.J. \& Shiel R.J. (2000) Impact of water regime and fish predation on zooplankton resting egg production and emergence. Journal of Plankton Research, 22, 433-446.

Ogden R.W. (2000) Modern and historical variation in aquatic macrophyte cover of billabongs associated with catchment development. Regulated Rivers: Research $\mathcal{E}$ Management, 16, 497-512.

Parks Victoria (2008) The Management Plan for Kings Billabong Wildlife Reserve. Parks Victoria, Melbourne.

Perga M.-E. (2010) Potential of \& \#x03B4;13C and \& \#x03B4;15N of cladoceran subfossil exoskeletons for pal- aeoecological studies. Journal of Paleolimnology, 44, 287395.

Perga M.-E. (2011) Taphonomic and early diagenetic effects on the $\mathrm{C}$ and $\mathrm{N}$ stable isotope composition of cladoceran remains: implications for palaeoecological studies. Journal of Paleolimnology, 46, 203-213.

Perga M.-E. \& Gerdeaux D. (2006) Seasonal variations in zooplankton species isotopic composition in two lakes of different trophic status. Acta Oecologica, 30, 69-77.

Post D.M. (2002) Using stable isotopes to estimate trophic position: models, methods, and assumptions. Ecology, 83, 703-718.

Reid M.A., Fluin J., Ogden R.W., Tibby J. \& Kershaw A.P. (2002) Long-term perspectives on human impacts on floodplain-river ecosystems, Murray-Darling Basin, Australia. Verhandlung der Internationale Vereinigung fer internationale und angewandte Limnologie, 28, 710-716.

Reid M.A., Sayer C.D., Kershaw A.P. \& Heijnis H. (2007) Palaeolimnological evidence for submerged plant loss in a floodplain lake associated with accelerated catchment soil erosion (Murray River, Australia). Journal of Paleolimnology, 38, 191-208.

Scheffer M., Hosper S.H., Meijer M.L., Moss B. \& Jeppesen E. (1993) Alternative equilibria in shallow lakes. Trends in Ecology E Evolution, 8, 275-279.

Segers R. (1998) Methane production and methane consumption: a review of processes underlying wetland methane fluxes. Biogeochemistry, 41, 23-51.

Shiel R.J. \& Dickson A. (1995) Cladocera recorded from Australia. Transaction of the Royal Society of South Australia, 119, 29-40.

Smiley E.A. \& Tessier A.J. (1998) Environmental gradients and the horizontal distribution of microcrustaceans in lakes. Freshwater Biology, 39, 397-409.

Szeroczynska K. \& Sarmaja-Korjonen K. (2007) Atlas of Subfossil Cladocera from Central and Northern Europe. Friends of the Lower Vistula Society, Poland.

Thorp J.H. \& Delong M.D. (1994) The riverine productivity model: an heuristic view of carbon sources and organic processes in large river ecosystem. Oikos, 70, 305-308.

Vadeboncoeur Y., Jeppesen E., Vander Zanden M.J., Schierup H.-H., Christoffersen K. \& Lodge D.M. (2003) From Greenland to green lakes: cultural eutrophication and the loss of benthic pathways in lakes. Limnology $\mathcal{E}$ Oceanography, 48, 1408-1418.

Van Hardenbroek M., Heiri O., Grey J., Bodelier P.L.E., Verbruggen F. \& Lotter A.F. (2010) Fossil chironomid \& \#x03B4;13C as a proxy for past methanogenic contribution to benthic food webs in lakes? Journal of Paleolimnolo$g y, 43,235-245$.

Vandekerkhove J., Declerck S., Vanhove M., Brendonck L., Jeppesen E., Conde Porcuna J.M. et al. (2004) Use of ephippial morphology to assess richness of anomopods: potentials and pitfalls. Journal of Limnology, 63(Suppl. 1), 75-84. 
Trophic structure and food web dynamics in floodplain wetland 13

Vannote R.L., Minshall G.W., Cummins K.W., Sedel J.R. \& Cushing C.D. (1980) The river continuum concept. Canadian Journal of Fisheries and Aquatic Sciences, 37, 130-137.

Vinyard G.L. \& O'Brien J. (1976) Effects of Light and Turbidity on the Reactive Distance of Bluegill (Lepomis macrochirus). Journal of the Fisheries Research Board of Canada, 33, 2845-2849.

Wehr J.D. \& Descy J.-P. (1998) Use of phytoplankton in large river management. Journal of Phycology, 34, 741-749.

(Manuscript accepted 10 November 2014) 